\title{
Coherence of clinical and histopathological diagnosis of most common skin lesions
}

\section{Ewa Ziajka', Jan Błaszczyk ${ }^{2}$}

${ }^{1}$ Individual Medical Practice, Haffnera str 12c, 81-717 Sopot, Poland, ${ }^{2}$ Departament of Human Physiology, Medical University of Lodz, Plac Hallera 1, Lodz, Poland

Corresponding author: Dr. Ewa Ziajka, E-mail: ewaziajka@wp.pl

\begin{abstract}
Background: Clinical evaluation of skin lesions is one of the most important methods of differentiating disease states, including the diagnosis of changes dangerous to the patient's health. Aim: The main aim of the work is to determine the coherence of the clinical diagnosis of the most frequently diagnosed states with a histopathological diagnosis. Material and Methods: The research material consisted of 709 medical records of people who underwent surgery to remove the skin lesion. A comparative analysis of clinical and histopathological diagnosis of most commonly diagnosed conditions was made in two directions. Results: The study group consisted mostly of women ( $\mathrm{n}=429,60.50 \%)$. The mean age in the study group was 49 years $(\mathrm{Me}=48)$. The histopathological assessment revealed more types of lesions than in the clinical procedure (73 vs. 38), in both cases the dye naevus was most common. Clinical and histopathological diagnosis differed in 398 cases (54.37\% of the total). The highest percentage of correct diagnoses was obtained in basal cell carcinoma (BCC) $(88.57 \%)$, actinic keratosis (77.72\%) and dye naevus (58.19\%). The worst coherence was found in case of hair cysts (0.00\%), cell naevus (7.63\%) and atypical dye naevus (19.05\%). In 22 cases, the changes originally described as benign were finally diagnosed as pre-cancer conditions or cancers. Both cases of melanoma were diagnosed incorrectly. Conclusions: The diagnostic compatibility of clinical and histopathological assessment is varied.
\end{abstract}

Key words: Dermatoscopy; Melanoma; Skin abnormalities 


\title{
Zgodność oceny klinicznej i histopatologicznej najczęściej występujących zmian skórnych
}

\author{
Ewa Ziajka ${ }^{1}$, Jan Błaszczyk ${ }^{2}$
}

\author{
${ }^{1}$ Individual Medical Practice, Haffnera str 12c, 81-717 Sopot, Poland, ${ }^{2}$ Departament of Human Physiology, Medical \\ University of Lodz, Plac Hallera 1, Lodz, Poland
}

Corresponding author: Dr. Ewa Ziajka, E-mail: ewaziajka@wp.pl

\begin{abstract}
STRESZCZENIE
Wprowadzenie: Kliniczna ocena zmian skórnych należy do najważniejszych metod różnicowania stanów chorobowych, w tym diagnozy zmian niebezpiecznych dla zdrowia pacjenta. Cel: Celem głównym pracy jest określenie zgodności diagnozy klinicznej najczęściej rozpoznawanych stanów z diagnozą histopatologiczną. Materiał i Metody: Materiał badawczy stanowiło 709 historii choroby osób, które przeszły zabieg usunięcia zmiany skórnej. Analizę porównawczą diagnozy klinicznej i histopatologicznej wśród najczęściej występujących stanów przeprowadzono dwukierunkowo. Wyniki: Grupa badana składała się w większości z kobiet $(n=429,60,50 \%)$. Średnia wieku w grupie badanej wyniosła 49 lat $(\mathrm{Me}=48)$. W ocenie histopatologicznej wykryto więcej rodzajów zmian niż w klinicznej (73 vs. 38), w obu przypadkach najczęściej występowało znamię barwnikowe. Diagnoza kliniczna i histopatologiczna różniły się w 398 przypadkach (54,37\% ogółu). Największy odsetek prawidłowych diagnoz uzyskano w przypadku raka podstawnokomórkowego BCC (88,57\%), rogowacenia słonecznego $(77,72 \%)$ i znamienia barwnikowego (58,19\%). Najgorszą spójność diagnoz uzyskano w torbieli mieszkowej (0,00\%), znamieniu komórkowym (7,63\%) i znamieniu barwnikowym atypowym (19,05\%). W 22 przypadkach zmiany pierwotnie określone jako łagodne należały do grupy stanów przedrakowych lub raków. Mylnie zdiagnozowano oba przypadki czerniaka. Wnioski: Zgodność diagnostyczna oceny klinicznej i histopatologicznej jest zróżnicowana.
\end{abstract}

Słowa kluczowe: Dermatoskopia; Czerniak; Choroby skóry

\section{WSTĘP}

Skóra jest największym organem w ciele człowieka, stanowiącym około $12 \%$ masy ciała. Jej powierzchnia u osoby przeciętnej budowy to około $2 \mathrm{~m}^{2}$. Skóra stanowi barierę ochronną wnętrza organizmu oraz bierze udział w procesie termoregulacji, czynnościach wydzielniczych i odpornościowych [1-4].

Znamiona skórne mogą mieć charakter łagodny (np. znamię brodawkowate, komórkowe, włókniak i inne), stanu przedrakowego (np. rogowacenie słoneczne, róg skórny, rogowacenie białe), raka przedinwazyjnego (choroba Bowena) lub nowotworu złośliwego (np. rak podstawnokomórkowy, rak kolczystokomórkowy, czerniak) [4-8].

Podstawowym sposobem określenia rodzaju zmian skórnych (wykwitów) jest ich ocena przez lekarza, gdzie rekomendowaną metodą jest dermatoskopia. W zakresie zmian niemelanocytowych stosuje się algorytm jednostopniowy, w ocenie zmian melanocytowych dwustopniowy. Schemat dwustopniowy uwzględnia algorytmy oceny takie jak ABCD/ABCDE, Lista 7 punktów, Metoda Menziesa lub analiza obrazów $[6,9,10]$. Każdy z nich cechuje się określonym stopniem czułości i swoistości, który uzależniony jest między innymi od doświadczenia lekarza i rodzaju diagnozowanej zmiany [11].

\section{CEL}

Celem głównym pracy jest określenie zgodności diagnostycznej w najczęściej występujących rodzajach zmian skórnych poprzez porównanie diagnozy lekarza postawionej na podstawie badania dermatoskopowego

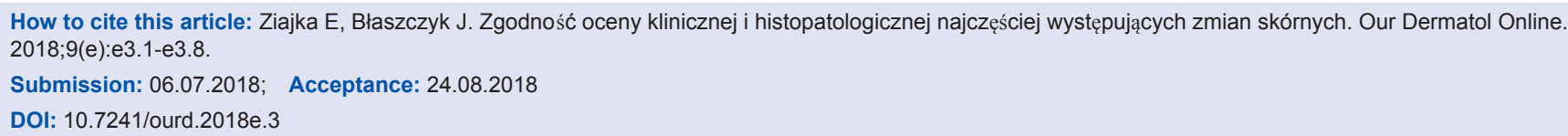


z wynikiem badania histopatologicznego. Ustanowiono także cele szczegółowe:

1. Określenie, w diagnostyce jakich zmian skórnych lekarze uzyskują najlepszą zgodność z wynikiem badania histopatologicznego.

2. Określenie, w diagnostyce jakich zmian skórnych lekarze uzyskują najgorszą zgodność z wynikiem badania histopatologicznego.

3. Określenie, jaka jest zgodność diagnoz w przypadku czerniaka.

\section{MATERIAŁ I METODY}

Materiał badawczy stanowiło 709 historii choroby pacjentów, którzy byli leczeni w Specjalistycznej Przychodni Lekarskiej Dla Pracowników Wojskowych i mieli usuniętą przynajmniej jedną zmianę skórną. Zmiana musiała zostać wstępnie zdiagnozowana przez lekarza, usunięta, a następnie zweryfikowana za pomocą badania histopatologicznego.

W badaniu zastosowano dwustronne porównanie najczęściej występujących stanów. W pierwszej kolejności porównano diagnozę kliniczną z histopatologiczną, a następnie przeprowadzono porównanie w odwrotnym kierunku - finalne rozpoznania histopatologiczne zostały porównane z wstępnymi diagnozami klinicznymi.

\section{WYNIKI}

\section{Grupa Badana}

Kobiety stanowiły większą część grupy badanej $(n=429$; $60,5 \%$ ), najczęściej były to osoby, które wykonywały pracę umysłową $(\mathrm{n}=151 ; 33,20 \%)$ (Tabela 1$)$.

\section{Charakterystyka Ogólna Usuniętych Zmian Skórnych}

Większość chorych miała jednorazowo usuniętą jedną zmianę - 80 osób miało usunięte 2 zmiany, a 9 osób trzy zmiany. $\mathrm{W}$ większości zmiany były małe i ich rozmiar nie przekraczał $0,5 \mathrm{~cm}(\mathrm{n}=498 ; 84,7 \%)$ - pozostałe dane przedstawiono w Tabeli 2 .

\section{Ocena Kliniczna Zmian Skórnych - Najczęściej Rozpoznawane Zmiany}

W ocenie klinicznej zmian skórnych klinicyści wyróżnili 38 rodzajów zmian. Do najczęściej rozpoznawanych należało znamię barwnikowe, które zdiagnozowano w 287 przypadkach (co stanowiło 39,15\% ogółu).
Tabela 1: Podstawowe dane demograficzne grupy badanej

\begin{tabular}{lccc}
\hline Parametr & $\begin{array}{c}\text { Ogółem } \\
\mathbf{n = 1 0 0 \%}\end{array}$ & $\begin{array}{c}\text { Kobiety } \\
\mathbf{n}(\%)\end{array}$ & $\begin{array}{c}\text { Mężczyźni } \\
\mathbf{n}(\%)\end{array}$ \\
\hline Liczba osób & $709(100)$ & $429(60,50)$ & $280(31,50)$ \\
\hline \multicolumn{4}{c}{ Wiek } \\
\hline średnia (+/- SD) & $49(+/-19,10)$ & $49(+/-18,82)$ & $48(+/-19,54)$ \\
mediana & 48 & 50 & 44 \\
wartość maksymalna & 92 & 91 & 92 \\
wartość minimalna & 11 & 12 & 11 \\
dominanta & 28 & 38 & 28 \\
\hline \multicolumn{4}{c}{ Zawód } \\
\hline bezrobotny & 15 & $14(93,33)$ \\
emeryt & 101 & $65(64,36)$ & $1(6,67)$ \\
inny & 30 & $18(60,00)$ & $12(45,64)$ \\
nauczyciel & 24 & $20(83,33)$ & $4(16,67)$ \\
prac. wojskowy & 151 & $40(26,49)$ & $111(73,51)$ \\
prac. fizyczny & 52 & $25(48,80)$ & $27(51,92)$ \\
prac. umysłowy & 237 & $185(78,06)$ & $52(21,94)$ \\
strażnik miejski & 53 & $33(62,26)$ & $20(37,74)$ \\
uczeń/student & 32 & $19(59,38)$ & $13(40,63)$ \\
b/d & 14 & $10(71,43)$ & $4(28,57)$ \\
\hline \multicolumn{5}{c}{ Fototyp skóry } \\
\hline Fototyp 1 & 0 & 0 & \\
Fototyp 2 & 139 & $93(66,91)$ & $46(33,09)$ \\
Fototyp 3 & 389 & $236(60,67)$ & $153(39,33)$ \\
Fototyp 4 & 172 & $94(54,65)$ & $78(45,35)$ \\
Fototyp 5 & 1 & $0(0,00)$ & $1(100)$ \\
b/d & 8 & $6(75,00)$ & $2(25,00)$ \\
\hline
\end{tabular}

Tabela 2: Charakterystyka zmian skórnych poddanych analizie

\begin{tabular}{lcc}
\hline Charakterystyka zmian & liczba & $\%$ \\
skórnych & & \\
\hline lokalizacja zmiany & 27 & 3,69 \\
brzuch, podbrzusze & 86 & 11,75 \\
głowa, szyja & 8 & 1,09 \\
jama ustna, warga & 84 & 11,48 \\
klatka piersiowa & 73 & 9,97 \\
kończyna dolna & 113 & 15,44 \\
kończyna górna & 6 & 0,82 \\
narządy płciowe, odbyt & 22 & 3,01 \\
pierś & 176 & 24,04 \\
plecy & 10 & 1,3 \\
pośladek & 106 & 14,48 \\
twarz & 21 & 2,87 \\
b/d & 732 & 100 \\
SUMA & & \\
\hline Sposób usunięcia zmiany & 563 & 76,91 \\
\hline całkowite & 84 & 11,48 \\
wycinek & 70 & 9,56 \\
styczne & 15 & 2,05 \\
b/d & 732 & 100 \\
\hline SUMA & 251 & \\
\hline Narażenie zmiany na promieniowanie słoneczne & 34,29 \\
\hline tak - zmiana odsłonięta & 459 & 62,70 \\
nie - zmiana zakryta & 22 & 3,01 \\
b/d & 732 & $100 \%$ \\
SUMA & & \\
\hline
\end{tabular}

Następną najczęściej diagnozowaną zmianą było znamię komórkowe, które rozpoznano w 118 przypadkach 
(16,10\% ogółu). Dziesięć najczęściej rozpoznawanych stanów zaprezentowano w Tabeli 3.

\section{Ocena Histopatologiczna Zmian Skórnych - Najczęściej Rozpoznawane Zmiany}

W badaniu histopatologicznym z kolei rozpoznano większą liczbę rodzajów zmian, bo 73 typy. Do najczęściej rozpoznawanych należało również znamię barwnikowe $(n=236)$, które stanowiło 32,20\% ogółu rozpoznań, następnie znamię komórkowe $(n=51)$, które stanowiło 6,96\% rozpoznań oraz rak podstawnokomórkowy $(\mathrm{n}=41)$, który stanowił 5,59\% rozpoznań (Tabela 4).

\section{Analiza Porównawcza Rozpoznań}

W analizie porównawczej zbiorczej, przeprowadzonej dla wszystkich znamion stwierdzono, że diagnoza kliniczna i histopatologiczna różniły się w 398 przypadkach, co stanowi 54,37\% ogółu analizowanych znamion. Następnie dokonano porównania poszczególnych diagnoz klinicznych z finalną diagnozą histopatologiczną. Porównanie przeprowadzono dla dziesięciu najczęściej diagnozowanych stanów (Tabela 5).

Tabela 3: Rodzaje rozpoznań najczęściej stawianych na podstawie oceny klinicznej

\begin{tabular}{llcc}
\hline \multicolumn{3}{l}{ Ocena kliniczna } & \multicolumn{2}{l}{ Liczba } & \% ogółu (100\%=732) \\
\hline LP & Rodzaj rozpoznania & 287 & 39,21 \\
\hline 1 & Znamię barwnikowe & 118 & 16,12 \\
2 & Znamię komórkowe & 50 & 6,83 \\
3 & Włókniak twardy & 35 & 4,78 \\
4 & Rak podstawnokomórkowy & 35 & 4,78 \\
5 & Znamię barwnikowe brodawkowate & 30 & 4,10 \\
6 & Brodawka łojotokowa & 24 & 3,28 \\
7 & Brodawka & 22 & 3,01 \\
8 & Rogowacenie słoneczne & 22 & 3,01 \\
9 & Torbiel mieszkowa & 21 & 2,87 \\
10 & Znamię barwnikowe atypowe & &
\end{tabular}

Tabela 4: Rodzaje rozpoznań postawionych na podstawie badania histopatologicznego

\begin{tabular}{llcc}
\hline \multicolumn{3}{l}{ Ocena histopatologiczna } & \\
\hline LP & Rodzaj rozpoznania & Liczba & \%ogółu (10\%=732) \\
\hline 1 & Znamię barwnikowe & 235 & 32,10 \\
2 & Znamię komórkowe & 51 & 6,97 \\
3 & Rak podstawnokomórkowy & 41 & 5,60 \\
4 & Włókniak twardy & 40 & 5,43 \\
5 & Brodawka łojotokowa barwnikowa & 39 & 5,33 \\
6 & Kaszak & 29 & 3,96 \\
7 & Plama soczewicowata & 24 & 3,28 \\
8 & Torbiel naskórkowa & 24 & 3,28 \\
9 & Rogowacenie słoneczne & 21 & 2,87 \\
10 & Brodawka tojotokowa & 20 & 2,73 \\
\hline
\end{tabular}

Ostatni etap analizy porównawczej stanowiło porównanie zwrotne diagnoz histopatologicznych ze stanami pierwotnie wskazanymi przez lekarzy (Tabela 6).

Precyzja procesu diagnostycznego była zróżnicowana. Najmniejszy odsetek poprawnych diagnoz uzyskano w torbieli mieszkowej, która nie została prawidłowo zdiagnozowana w ani jednym przypadku. Najwięcej prawidłowych diagnoz stwierdzono w przypadku BCC (Fig. 1).

Wśród mylnie zdiagnozowanych zmian znalazły się te, które należy uznać za niebezpieczne dla zdrowia pacjenta, tj. zmiany atypowe, dysplastyczne, przedrakowe lub nowotworowe.

Porównując diagnozy pierwotnie określone jako łagodne okazuje się, że w 22 przypadkach gdyby nie badanie weryfikacja histopatologiczna pacjenci nie zostaliby poinformowani o fakcie występowania u nich stanu niebezpiecznego dla zdrowia (w tym o jednym przypadku czerniaka). Znamię barwnikowe w 18 przypadkach okazywało się być finalnie plamą soczewicowatą, w jednym przypadku łagodna brodawka łojotokowa okazała się rogowiakiem kolczystokomórkowym i w jednym przypadku czerniakiem. Brodawka pomylona została w jednym przypadku z plamą soczewicowatą i również w jednym przypadku z chorobą Bowena. Dodatkowo, jedno znamię barwnikowe o cechach atypii okazało się finalnie czerniakiem.

\section{DYSKUSJA}

Postawienie prawidłowej diagnozy zmian skórnych na podstawie ich oglądu nie należy do łatwych. Choroby te charakteryzuje szereg dyskretnie różniących się symptomów, które niekiedy nie sposób odróżnić na podstawie oceny wzrokowej (nawet okiem uzbrojonym w dermatoskop). Zasady rozpoznawania zmian na podstawie oceny klinicznej, głównie z wykorzystaniem dermoskopii, znane są od dziesiątków lat i opisane między innymi w pracach Argenziano czy innych znamienitych autorów [12-15], jednakże dyskusja światowa w zakresie zwiększania efektywności tej metody, jej uniwersalizacji nie może być uznana za zakończoną.

Jeszcze w latach 60 i 70 XX wieku, diagnoza kliniczna czerniaka skóry opierała się przede wszystkim na ocenie takich symptomów jak krwawienie, świąd oraz owrzodzenie, których wspólne występowanie 
www.odermatol.com

Tabela 5: Analiza porównawcza diagnoz klinicznych i histopatologicznych dla dziesięciu najczęściej diagnozowanych stanów

\begin{tabular}{|c|c|c|c|c|}
\hline \multirow[t]{2}{*}{ Diagnoza kliniczna } & \multicolumn{4}{|l|}{ Diagnoza histopatologiczna } \\
\hline & Nazwa & liczba & $\begin{array}{c}\% \text { w grupie źle } \\
\text { zdiagnozowanych }\end{array}$ & $\begin{array}{c}\% \text { znamion danego } \\
\text { rodzaju (diagnoz hist-pat) }\end{array}$ \\
\hline \multirow[t]{3}{*}{ Znamię barwnikowe } & Znamię komórkowe & 19 & 15,83 & 6,62 \\
\hline & Plama soczewicowata & 18 & 15,00 & 6,27 \\
\hline & Znamię błękitne & 10 & 8,33 & 3,48 \\
\hline \multirow[t]{4}{*}{ Znamię komórkowe } & Znamię barwnikowe & 25 & 22,94 & 21,19 \\
\hline & Brodawka tojotokowa barwnikowa & 16 & 14,68 & 13,56 \\
\hline & Znamię barwnikowe złożone & 6 & 5,50 & 5,08 \\
\hline & Znamię skórne polipowate & 6 & 5,50 & 5,08 \\
\hline \multirow[t]{5}{*}{ Włókniak twardy } & Torbiel naskórkowa & 5 & 25,00 & 10,00 \\
\hline & Tłuszczak & 2 & 10,00 & 4,00 \\
\hline & Neurofibroma & 2 & 10,00 & 4,00 \\
\hline & Znamię barwnikowe & 2 & 10,00 & 4,00 \\
\hline & Znamię brodawkowate & 2 & 10,00 & 4,00 \\
\hline \multirow[t]{4}{*}{$\mathrm{BCC}$} & Znamię Suttona & 1 & 25,00 & 2,86 \\
\hline & Rogowiak kolczystokomórkowy & 1 & 25,00 & 2,86 \\
\hline & Brodawka łojotokowa barwnikowa & 1 & 25,00 & 2,86 \\
\hline & Rogowacenie słoneczne & 1 & 25,00 & 2,86 \\
\hline \multirow[t]{3}{*}{ Znamię barwnikowe brodawkowate } & Znamię barwnikowe & 16 & 61,54 & 45,71 \\
\hline & Znamię komórkowe & 4 & 15,38 & 11,43 \\
\hline & Brodawka łojotokowa barwnikowa & 3 & 11,54 & 8,57 \\
\hline \multirow[t]{4}{*}{ Brodawka łojotokowa } & Brodawka tojotokowa barwnikowa & 11 & 78,57 & 36,67 \\
\hline & Rogowiak kolczystokomórkowy & 1 & 7,14 & 3,33 \\
\hline & Czerniak & 1 & 7,14 & 3,33 \\
\hline & Znamię barwnikowe brodawkowate & 1 & 7,14 & 3,33 \\
\hline \multirow[t]{12}{*}{ Brodawka } & Brodawka łojotokowa barwnikowa & 3 & 18,75 & 12,50 \\
\hline & Brodawczak & 2 & 12,50 & 8,33 \\
\hline & Brodawka łojotokowa & 2 & 12,50 & 8,33 \\
\hline & Włókniakonaczyniak & 1 & 6,25 & 4,17 \\
\hline & Plama soczewicowata & 1 & 6,25 & 4,17 \\
\hline & Naczyniak & 1 & 6,25 & 4,17 \\
\hline & Choroba Bowena & 1 & 6,25 & 4,17 \\
\hline & Kaszak & 1 & 6,25 & 4,17 \\
\hline & Torbiel naskórkowa & 1 & 6,25 & 4,17 \\
\hline & Znamię barwnikowe złożone & 1 & 6,25 & 4,17 \\
\hline & Znamię barwnikowe & 1 & 6,25 & 4,17 \\
\hline & Znamię brodawkowate & 1 & 6,25 & 4,17 \\
\hline \multirow[t]{2}{*}{ Rogowacenie słoneczne } & Rak podstawnokomórkowy & 4 & 80,00 & 18,18 \\
\hline & Brodawka tojotokowa barwnikowa & 1 & 20,00 & 4,55 \\
\hline \multirow[t]{4}{*}{ Torbiel mieszkowa } & Kaszak & 16 & 72,73 & 72,73 \\
\hline & Torbiel naskórkowa & 4 & 18,18 & 18,18 \\
\hline & Znamię komórkowe & 1 & 4,55 & 4,55 \\
\hline & Znamię Spitz & 1 & 4,55 & 4,55 \\
\hline \multirow[t]{4}{*}{ Znamię barwnikowe atypowe } & Znamię barwnikowe & 11 & 64,71 & 52,38 \\
\hline & Plama soczewicowata & 3 & 17,65 & 14,29 \\
\hline & Znamię komórkowe & 2 & 11,76 & 9,52 \\
\hline & Czerniak & 1 & 5,88 & 4,76 \\
\hline
\end{tabular}

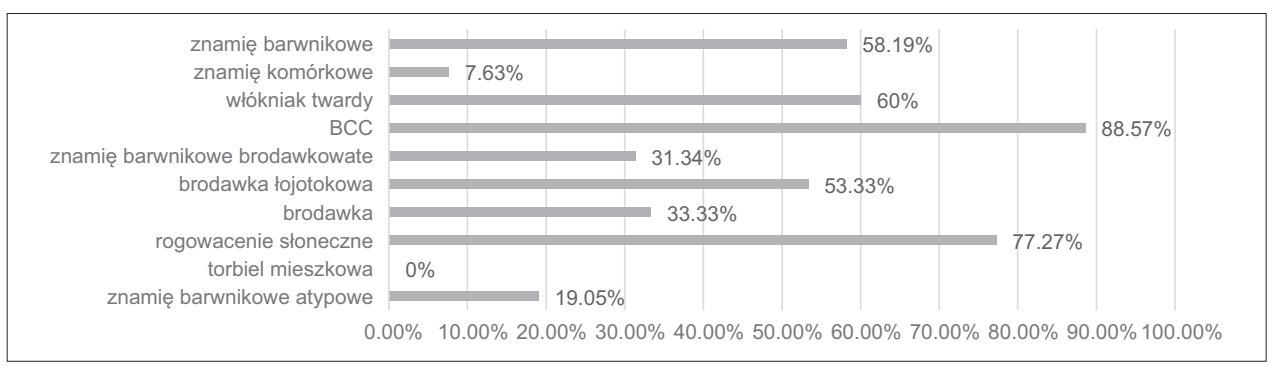

Rycina 1: Odsetek poprawianych diagnoz wśród najczęściej stawianych w ocenie klinicznej diagnoz. 
Tabela 6 :Analiza porównawcza diagnoz histopatologicznych i klinicznych ( „>” oznaczono przypadki, w których liczba niepoprawnych diagnoz była większa od liczby diagnoz prawidłowych)

\begin{tabular}{|c|c|c|c|c|}
\hline \multirow[t]{2}{*}{ Diagnoza histopatologiczna } & \multicolumn{4}{|l|}{ Diagnoza kliniczna } \\
\hline & Nazwa & liczba & $\begin{array}{l}\% \text { niepoprawnych } \\
\text { diagnoz klinicznych }\end{array}$ & $\begin{array}{c}\% \text { poprawnych diagnoz } \\
\text { klinicznych }\end{array}$ \\
\hline \multirow[t]{3}{*}{ Znamię barwnikowe } & znamieniem komórkowym & 16 & 30,77 & 8,74 \\
\hline & znamieniem barwnikowym brodawkowatym & 15 & 28,85 & 8,20 \\
\hline & Znamię barwnikowe atypowe & 11 & 21,15 & 6,01 \\
\hline \multirow[t]{4}{*}{ Znamię komórkowe } & Znamię barwnikowe & 20 & 60,61 & $>$ \\
\hline & Znamię barwnikowe brodawkowate & 5 & 15,15 & 27,78 \\
\hline & Znamię barwnikowe atypowe & 2 & 6,06 & 11,11 \\
\hline & Znamię komórkowe brodawkowate & 2 & 6,06 & 11,11 \\
\hline \multirow[t]{2}{*}{$\mathrm{BCC}$} & Rogowacenie słoneczne & 4 & 40,00 & 12,90 \\
\hline & Znamię komórkowe & 3 & 30 & 9,68 \\
\hline \multirow[t]{2}{*}{ Włókniak twardy } & Znamię barwnikowe & 4 & 44,44 & 12,90 \\
\hline & Znamię komórkowe & 3 & 33,33 & 9,68 \\
\hline \multirow[t]{2}{*}{ Brodawka łojotokowa barwnikowa } & Znamię komórkowe & 13 & 33,33 & $>$ \\
\hline & Brodawka łojotokowa & 11 & 28,21 & $>$ \\
\hline \multirow[t]{2}{*}{ Kaszak } & Torbiel mieszkowa & 16 & 76,16 & $>$ \\
\hline & Znamię barwnikowe & 3 & 14,29 & 37,50 \\
\hline \multirow[t]{2}{*}{ Plama soczewicowata } & Znamię barwnikowe & 18 & 78,26 & $>$ \\
\hline & Znamię barwnikowe atypowe & 3 & 13,04 & $>$ \\
\hline \multirow[t]{4}{*}{ Torbiel mieszkowa } & Włókniak twardy & 5 & 22,73 & $>$ \\
\hline & Znamię komórkowe & 4 & 18,18 & $>$ \\
\hline & Torbiel mieszkowa & 4 & 18,18 & $>$ \\
\hline & Kaszak & 4 & 18,18 & $>$ \\
\hline \multirow[t]{4}{*}{ Rogowacenie słoneczne } & znamię barwnikowe & 1 & 5,88 & 5,88 \\
\hline & Choroba Bowena & 1 & 5,88 & 5,88 \\
\hline & $\mathrm{BCC}$ & 1 & 5,88 & 5,88 \\
\hline & Znamię komórkowe & 1 & 5,88 & 5,88 \\
\hline
\end{tabular}

uznawano za wskazujące na czerniaka. Wiązało się to jednak z małą precyzją i diagnoza rzadko okazywała się trafna. Jak wskazują Friedman i wsp. w latach 80 XX wieku wprowadzono zasadę ABCD, która zwiększyła efektywność oceny klinicznej zmian skórnych [16], jednakże wciąż pozostawała niedoskonałą - zwłaszcza w odniesieniu do małych zmian (do $5 \mathrm{~mm}$ ). Już wówczas miano świadomość, że jej niedoskonałości mogą wywoływać wiele niepotrzebnych zabiegów chirurgicznych związanych z usuwaniem zmian łagodnych (mała swoistość), ale równocześnie wskazywano na konieczność doskonalenia metody, a nie odrzucanie jej [11]. Doskonalenie sprzętu, jak wskazuje np. Rigel i inni $[15,17]$ (w XXI wieku wprowadzono np. ocenę metodami cyfrowymi) i nabywanie umiejętności przez lekarzy doprowadziło do dalszego zwiększania parametrów precyzji. Na podstawie prac przeglądowych autorzy szacują, że obecnie dermatolog jest w stanie prawidłowo zdiagnozować czerniaka w około 65-80\% przypadków [14,18].

Należy nadmienić, że aktualnie (dane US Preventive Services Task Force z 2016 roku) posiadane dowody naukowe pozwalają stwierdzić, że ocena kliniczna w czerniaku charakteryzuje się wciąż ograniczoną czułością i swoistością [19]. Opinia ta wydaje się być zgodna z uzyskanymi w niniejszej pracy wynikami. Wartym zauważenia jest fakt, że w znacznym zakresie klinicyści dobrze poradzili sobie z różnicowaniem zmian, np. w przypadku BCC czy rogowacenia słonecznego oraz to, że omawiana metoda jest nieinwazyjna, dobrze akceptowana przez pacjentów, tania i możliwa do wykonania właściwie w każdym momencie. Zgodnie z danymi Oliveria i wsp. jest to badanie często wykonywane w praktyce lekarskiej. Wyniki ankiety przeprowadzonej wśród amerykańskich lekarzy wykazały, że wzrokową ocenę całego ciała z wykorzystaniem reguły ABCDE wykonuje u swoich pacjentów $81 \%$ dermatologów, 90\% lekarzy rodzinnych i 56\% lekarzy internistów [20]. Wraz z rosnącym doświadczeniem klinicysty, badanie to staje się strategicznym narzędziem w wykrywaniu czarniaka skóry, pozwalającym na postawienie prawidłowej diagnozy w 65-90\%, a nawet 95\% [21-24]. Ocena kliniczna dokonana przez sprawnego diagnostę wciąż pozostaje ważnym i najłatwiej dostępnym rodzajem badania wykonywanym w diagnostyce raka skóry. Biorąc pod uwagę jednak jej ograniczoną precyzję, nie należy jej traktować jako samodzielnego badania skriningowego. 
W przedstawianym badaniu znamiona były częściej wykrywane u kobiet, które stanowiły 60,50\% grupy badanej. Średnia wieku oraz mediana wyniosły odpowiednio 49 i 48 lat. Podobną medianę wieku wykazano w badaniu australijskim autorstwa Youl i wsp. z 2007 roku - wyniosła ona 51,5 roku [25]. Należy pamiętać, iż Australia należy do krajów o największym współczynniku zachorowalności na raka skóry i badania prowadzone w tym kraju obejmują zazwyczaj duże grupy pacjentów (w przytoczonym badaniu blisko 20000 osób). W niniejszym badaniu najczęstszą lokalizacją zmian były plecy (korpus) (24,04\%), kończyna górna $(15,44 \%)$ i twarz $(14,48 \%)$. Jest to zbieżne z wynikami innych badaczy [26-32].

Klinicyści uzyskali największy odsetek poprawnych diagnoz w przypadku BCC, co należy uznać za sytuację korzystną, jako że ocena kliniczna BCC nie należy do łatwych. Christensen i wsp. wskazał, iż może być on pomylony z wieloma innymi znamionami, ze względu na brak łatwych do wychwycenia jednoznacznych cech różnicujących. Uwagę zwrócono również na cechy takie jak trudny do dokładnej oceny rozrost guza, który charakteryzuje się niekiedy subklinicznym głębokim rozrostem wewnątrz tkanek [33]. Podobne badanie zostało zrealizowane w 2015 roku przez EbrahimzadehArdakani i wsp., w którym porównywano wykrywalność BCC w ocenie klinicznej, którą weryfikowano poprzez porównanie diagnozy klinicznej z wynikami badania histopatologicznego. Wykazano, że lekarze cechują się diagnostyczną czułością na poziomie około 84,4\%, przy czym jest ona większa dla dermatologów niż lekarzy innych specjalności, np. lekarzy rodzinnych [34].

Klinicyści przeoczyli oba przypadki czerniaka występujące w grupie badanej. Inni autorzy również wskazywali, że najgorsze parametry precyzji klinicznej są osiągane przez lekarzy właśnie w przypadku czerniaka. Grupę raków, BCC, SCC i czerniaków analizował także Youl i wsp., najgorsze parametry (czułość na poziomie 60,00\% i swoistość 98,00\%) uzyskując dla czerniaka [25].

\section{WNIOSKI}

Zgodność diagnostyczna oceny klinicznej i histopatologicznej najczęściej występujących rodzajów zmian skórnych jest zróżnicowana.

1. Najlepszą zgodność lekarze osiągają w przypadku raka podstawnokomórkowego, rogowacenia słonecznego i znamienia barwnikowego.
2. Najgorszą zgodność lekarze uzyskują w przypadku torbieli mieszkowej, znamienia komórkowego i znamienia barwnikowego atypowego.

3. Lekarze nie zdiagnozowali prawidłowo żadnego z dwóch przypadków czerniaka myląc go ze znamieniem barwnikowym atypowym i brodawką łojotokową.

\section{Statement of Human and Animal Rights}

All procedures followed were in accordance with the ethical standards of the responsible committee on human experimentation (institutional and national) and with the Helsinki Declaration of 1975, as revised in 2008 .

\section{Statement of Informed Consent}

Informed consent was obtained from all patients for being included in the study.

\section{REFERENCES}

1. Elsy B, Khan AA, Maheshwari V. Effect of vitamin E isoforms on the primary intention skin wound healing of diabetic rats. Our Dermatol Online. 2017;8:369-75.

2. Borowska K. How narrow-band and broad-band uvb irradiation influences the histomorphology evaluations of experimental animals' skin - a comparative study. Part I. Our Dermatol Online. 2017;8(3e):e5.

3. Janovska J, Voicehovska J, Kasparane L. Sun induced skin damage and immunosuppression. Rom J Clin Exp Dermatol. 2015;2:84-90.

4. Finn M, Smith N, Segars L, Burns E, Peterson J, Sutton A, et al. Melanoma and medical education: student's perceptions of skin cancer screening in three medical schools. Our Dermatol Online. 2018;9:123-7.

5. Ouédraogo AS, Ramdé NW, Ouédraogo MS, Assita L-S, Ido FAHA, Savadogo I, et al. [The benign tumours of skin adnexal diagnosed in Ouagadougou: Histopathological and epidemiological profile]. Our Dermatol Online. 2017;8:393-8.

6. Cengiz FP, Emiroglu N, Bahali AG, Su O, Onsun N. Malignant melanoma arising in congenital melanocytic nevi: clinical and dermoscopic challenges. Our Dermatol Online. 2017;8:34-6.

7. Diabaté A, Kourouma HS, Vagamon B, Gué I, Kaloga M, Aka BR. Skin pathology of the elderly patients: Case of black African. Our Dermatol Online. 2018;9:19-21.

8. Martini L, Brzezinski P. The demonstration that amongs myriads of palliative anticancer plants, there is one that is endowed by a synergical action: The Chenopodium album, that avoids the biotranformation of a benign skin tumor to malignant. Our Dermatol Online. 2018;9:316-9.

9. Solomon I, Lupu M, Draghici CC, Voiculescu VM, Giurcaneanu C. Dermatoscopic pattern variability in basal cell carcinoma implications in diagnosis, preoperative assessment, and tumor management. Rom J Clin Exp Dermatol. 2018;5:36-42.

10. Malakar S, Mukherjee SS, Malakar S. Uniform faint reticulate pigment network - A dermoscopic hallmark of nevus depigmentosus. Our Dermatol Online. 2018;9:225-6.

11. Abdulaziz A, Brzezinski P, Chiriac A. Skin of sailor: Cutis rhomboidalis nuchae, actinic keratosis, squamous cell carcinoma and basal cell carcinoma. Case report. Onco Rev. 2014;4:A36-40. 
12. Blum A, Kreusch J, Stolz W, Argenziano G, Forsea AM, Marmol VD, et al. The status of dermoscopy in Germany - results of the crosssectional Pan-Euro-Dermoscopy Study. J Dtsch Dermatol Ges. 2018;16:174-81.

13. Raducu L, Filip I, Cozma CN, Ardeleanu V, Stefanescu O, Jecan RC. A review of frequent cutaneous malignancies - part II: malignant melanoma. Rom J Clin Exp Dermatol. 2017;3:166-73.

14. Wazaefi Y, Gaudy-Marqueste C, Avril MF, Malvehy J, Pellacani G, Thomas L, et al. Evidence of a limited intra-individual diversity of nevi: intuitive perception of dominant clusters is a crucial step in the analysis of nevi by dermatologists. J Invest Dermatol. 2013;133:2355-61.

15. Drljević I, Bjelošević E, Denjalić A, Drljević K. Melanocytic lesions and dermoscopy in childhood: diagnosis, therapy and foloving. Our Dermatol Online. 2016;7:97-100.

16. Friedman R, Rigel D, Kopf A. Early detection of malignant melanoma: the role of physician examination and self-examination of the skin. CA Cancer J Clin. 1985;35:130-51.

17. Rigel D. Epiluminescence microscopy in clinical diagnosis of pigmented skin lesions? Lancet. 1997;349:1566-7.

18. Rudnicka L, Olszewska M, Słowińska M. Wczesna diagnostyka czerniaka złośliwego skóry i śluzówek jamy ustnej. Wsp Onkol, 2003;7:556-63.

19. US Preventive Services Task Force, Bibbins-Domingo K, Grossman DC, et al. Screening for Skin Cancer US Preventive Services Task Force Recommendation Statement. JAMA. 2016;316:429-35.

20. Oliveria S, Heneghan M, Cushman L, Ughetta E, Halpern A. Skin cancer screening by dermatologists, family practitioners, and internists: barriers and facilitating factors. Arch Dermatol. 2011;147:39-44.

21. Nufer KL, Raphael AP, Soyer HP. Dermoscopy and Overdiagnosis of Melanoma In Situ. JAMA Dermatol. 2018;154:398-9.

22. Carrera C, Segura S, Aguilera P, Takigami CM, Gomes A, Barreiro A, et al. Dermoscopy Improves the Diagnostic Accuracy of Melanomas Clinically Resembling Seborrheic Keratosis: CrossSectional Study of the Ability to Detect Seborrheic Keratosis-Like Melanomas by a Group of Dermatologists with Varying Degrees of Experience. Dermatology. 2017;233:471-9.

23. Cioplea M, Zurac S, Popp C, Nichita L, Stinga P, Cioroianu A, et al. Malignanat melanoma in young patients: histopathologic particularities. Rom J Clin Exp Dermatol. 2018;5:12-7.

24. Malakar S, Mukherjee SS. Dermoscopy unveils the mystery of a deceptive nodule!. Our Dermatol Online. 2017;8:495-6.

25. Youl P, Baade P, Janda M, Del Mar C, Whiteman D, Aitken A. Diagnosing skin cancer in primary care: how do mainstream general practitioners compare with primary care skin cancer clinic doctors? Med J Aust. 2007;187:215-20.

26. Altamura D, Menzies S, Argenziano G, Zalaudek I, Soyer H, Sera F, et al. Dermatoscopy of basal cell carcinoma: Morphologic variability of global and local features and accuracy of diagnosis. J Am Acad Dermatol. 2010;62:67-75.

27. Bartoš V, Bulejčíková T. Basal cell carcinoma of the skin with clear cell differentation: A report of two cases. Our Dermatol Online. 2016;7:422-6.

28. Bel Haj Salah M, Zaouek A, Smichi I, Koubâa W, Chadly-Debbiche A. Pleomorphic basal cell carcinoma: report of an uncommon histological variant. Our Dermatol Online. 2015;6:479-80.

29. Gundalli S, Kolekar R, Kolekar A, Nandurkar V, Pai V, Nandurkar S. Study of basal cell carcinoma and its histopathological variants. Our Dermatol Online. 2015;6:399-403.

30. Bartoš V, Bulejčíková T. Basal cell carcinoma of the skin with clear cell differentation: A report of two cases. Our Dermatol Online. 2016;7:422-6.

31. Bartoš V, Kullová M. Immunohistochemical evaluation of E-cadherin expression in basal cell carcinoma of the skin. Our Dermatol Online. 2015;6:257-64.

32. Braga GM, Riveros R, Di Ortiz BM, Recalde J, Bolla L. Dermatoscopy: contribution as a method to define surgical margins in basal cell carcinoma of the fase, neck and trunk. Our Dermatol Online. 2013;4:28-31.

33. Christensen E, Mjones P, Grimstad O, Rordam O, Foss O. Comparison of clinical and histopathological evaluations of basal cell carcinoma thickness. Br J Dermatol. 2015;173:578-80.

34. Ebrahimzadeh-Ardakani M, Moghimi M, Kafaie P, Dehghani F, Rashidi A, Shojaoddiny-Ardekani A. Assessment of clinical diagnostic accuracy compared with pathological diagnosis of basal cell carcinoma. Indian Dermatol Online. 2015;6:258-62.

Copyright by Ewa Ziajka, et al. This is an open access article distributed under the terms of the Creative Commons Attribution License, which permits unrestricted use, distribution, and reproduction in any medium, provided the original author and source are credited.

Source of Support: Nil, Conflict of Interest: None declared. 